\title{
Libraries and athletics at Texas A\&M: A winning team
}

\author{
By Nancy H. Marshall
}

\section{Creating a vibrant image for the library}

$\mathbf{T}$ he Sterling C. Evans Library at Texas A\&M University won a 1996 John Cotton Dana Library Public Relations Award for its successful fundraising and public relations partnership between libraries and athletics. With football coach R. C. Slocum and library dean Fred Heath "Advancing the Library into the Big 12" together, university athletics and academics became a winning team.

"The John Cotton Dana Award is one of the most coveted honors of the profession, one to which virtually all library administrators aspire. Our award recognizes a partnership of the library, its Friends group, and athletics," said Heath.

The award, jointly sponsored since 1946 by the H. W. Wilson Company and ALA's Library Administration and Management Association's Public Relations Section, was one of ten presented to various types of libraries and library organizations for outstanding public relations programming. A reception celebrating the 50th anniversary of the awards, with current and past winners and library leaders present, was given at the ALA Annual Conference in New York, and was funded by the $\mathrm{H}$. W. Wilson Company.

In her comments during the ceremony, Amy Small, chair of this year's John Cotton Dana judging jury, said, "Both John Cotton Dana and the Wilson Company were ahead of their time in recognizing the importance of public relations and promotion to libraries. These awards have set a standard and model of creativity and professionalism."

\section{A model partnership: Academics and athletics}

With the dismantling of the Southwest Confer ence to which Texas A\&M belonged, the university along with other Texas institutions moved into the Big 8 creating a new Big 12 Conference. The move, coupled with the library's increased funding and expansion plans, provided the impetus for a multifaceted public relations effort that combined new and existing programs, activities, and relationships into an integrated public relations effort. Heath wanted people to realize that the library, not just the football team, was entering the Big 12 and that Texas A\&M deserved a worthy library with a respectable ranking. The fundamental purpose of the Big 12 public relations campaign, according to Heath, was to position the

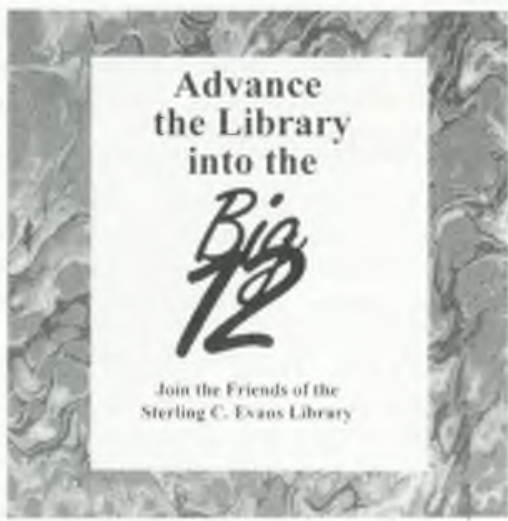

Friends of the Sterling C. Evans Library at Texas A\&M University have put out this brochure to promote the library. The inside text reads: "When Texas A\&M joins the Big 12 so does its library." 


\title{
A CURE FOR AIDS WILL HAVE TO GET PAST THE FDA.
}

\author{
The World Health Organization.
}

\section{And the Centers for Disease Control.}

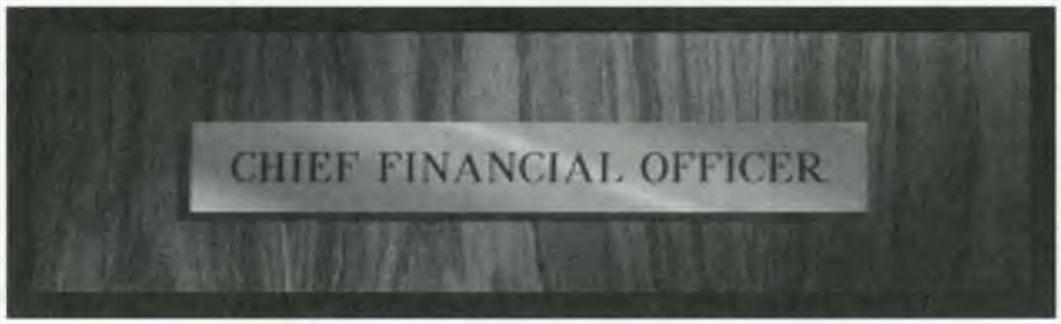

\section{BUT FIRST IT'S GOT TO GET PAST SOMEONE ELSE.}

As much as we'd like to think that profit plays no part in medical breakthroughs, the biotechnology and health care industries are businesses - with justifiable needs to pursue healthy bottom lines. But what if business chose to save money over lives?

You can explore all sides of this and other critical public and social policy issues through PAIS International. PAIS gives you instant access to an index of some 400,000 hard-to-find articles, books, government documents,

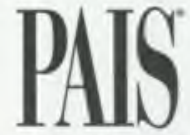

statistical directories and more. It references literature published around the globe. And now it's even available on leased tape.

So if you're looking for information, go through the right channel. Use PAIS.

Public Affairs Information Service, Inc.

NO ONE LOOKS AT THE WORLD LIKE PAIS

\section{Now ayallagle: Pais Select, ouf new full-text cD-fom. CALL TODAY TO TAKE ADVANTAGE OF INTRODUCTORY PRICING.}

On CD-ROM: PAIS ON CD-ROM. PAIS SELECT FULL-TEXT • PAIS INTERNATIONAL ON SILVERPLATTER - PAISIEBSCO CD EBSCOHOST - INFOTAAC SEARCHBANK - OCLC - OVID. ALG On Magnetic Tape: CONTACT PAIS FOA INFORMATION 


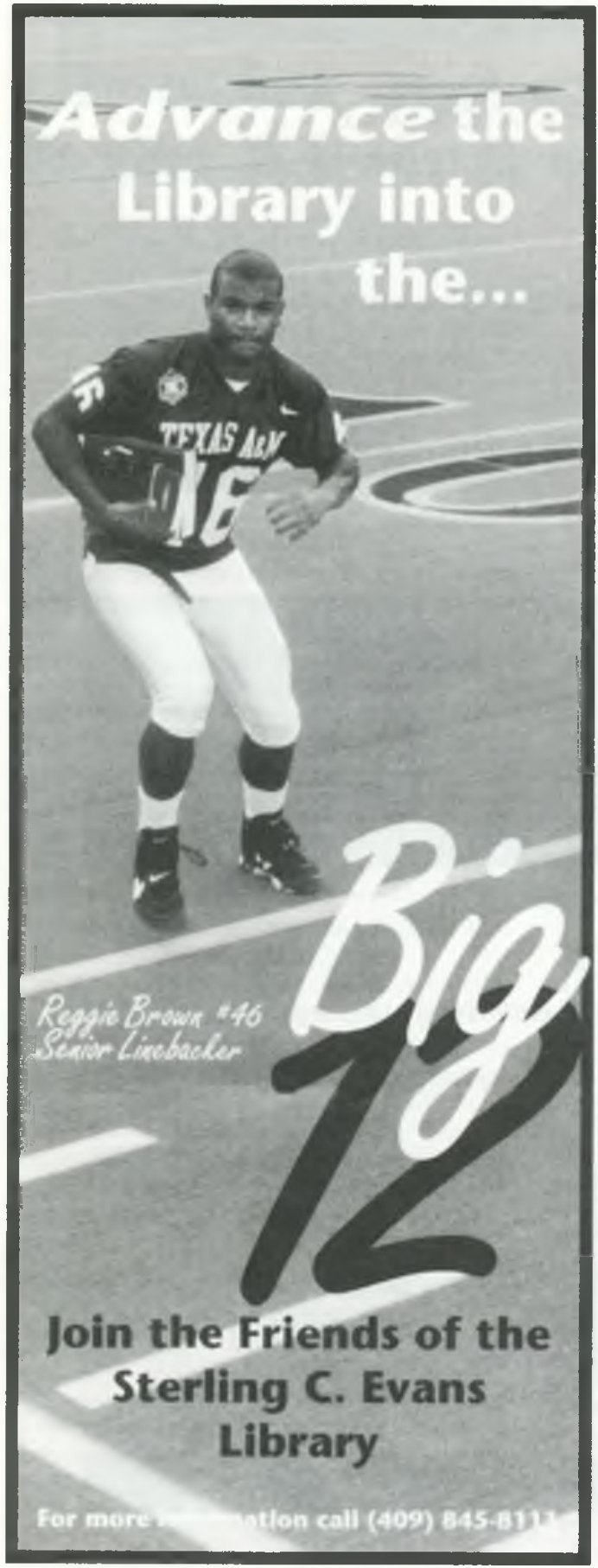

Part of Texas A\&M's campaign to "advance the library into the Big 12." libraries at Texas A\&M to realize their potential and to accomplish this through an active partnership with athletics.

The library's public relations strategy centered on two key relationships: athletics and the Friends of the Library. The key components of the strategy consisted of: 1) coach Slocum's Aggie Football Kick-off Camp and his Home Sports Entertainment program, 2) the Friends' renewal/recruitment plan, 3) the Friends Fun Run, and 4) Library Textbook Scholarships. Both athletics and the Friends were already providing financial support to the library. The Aggie Kick-off Camp, an adult summer camp for affluent football devotees, had generated between $\$ 9,000$ and $\$ 12,000$ per year over the past several years. The emphasis on this campaign, however, was not so much on fundraising as on creating a vibrant image and forging strong relationships for the future. The ultimate goal was widespread coverage and recognition for the library. The dean took advantage of the momentum of Texas A\&M's move to the Big 12 to launch a campaign with an athletic theme to heighten appreciation for the library and revitalize its image among current and former students.

\section{Share your public relations successes}

The John Cotton Dana Awards have been given annually since 1946 to honor the career of John Cotton Dana (1856-1929), an eminent librarian who was a pioneer in using public relations techniques to promote libraries. Entries are judged on four major criteria and on overall creativity and presentation. Judges evaluate implementation (40\%), assessment $(15 \%)$, evaluation $(15 \%)$, overall creativity $(5 \%)$, presentation of the entry $(5 \%)$, and planning ( $2 \%)$. Make plans to enter and request 1997 information and entry forms from the $\mathrm{H}$. W. Wilson Co., 950 University Ave., Bronx, NY 10452-9978. Attn: John Cotton Dand Awards. The deadline for the next competition is February 14, 1997. 


\section{Try these winning PR ideas}

If you have run out of ideas to promote your library, consider trying a few of these public relations activities from past John Cotton Dana contest participants, or borrow winning entries from the ALA headquarters library. Ed. note: To borrow materials submit an ALA-accredited interlibrary loan form to the ALA Library and Research Center, 50 E. Huron St., Chicago, IL 60611 or fax: (312) 280-3255.

1 Sponsor a cultural or ethnic festival that features library materials, staff, and services.

Develop a program with a "catchy" theme to convince state legislators to invest more money in library services and fund new technology to help all citizens get ready for the 21 st century.

- Raise funds for the library with a

celebrity roast or other similar special event.

4 Promote anything new-a library building, remodeling project, dedication anniversary or service.

Introduce with great fanfare library automation projects, new services, special acquisitions.

Take statewide approaches to issues such as literacy, and involve libraries, education, government, business, and community leaders.

7 Prepare eye-catching exhiloits displaying library materials, issues, or hot topics of interest, and use multimedia to enhance the presentation.

: Involve your users, Friends, and trustees in fundraising and promotional events, and remember to have fun in your PR efforts.

\section{Piercing Social Analysis}

Antennas pierce the sky. Receptive and olert, taking information from the airwaves, and bringing it into our homes, night affer night, day after day. What do they say about us? Do they serve us by shaping our understand. ing of the world? $\mathrm{Or}$, are we merely the hypnolized captives of for distant programmers? We accept many things without seeing the bigger picture.

But, if you're looking for penelraling insights about everyday life, individuals and societies large and small around the globe, there are two ploces to start.

Sociological Abstracts (sa) and Social Planning/Policy \& Development Abstracts (SOPODA).

Our data are drawn from more than 2,000 serials from 35 countries, along with books, conference papers, book and other media reviews and dissertations

You'll find the piercing sociol analysis that plugs you into the real world.

\section{sociological abstracts, ine.}

PO. Box 22206, San Diego, CA 92192.0206 619/695-8803, Fax; 695-0416 Inlernet: socio@cerfnet.com User Assistance: 800/752:3945

Serving the sociological community since 1953

The SAI family of serivces: Sociological Abstracts (SA) - Social Planning/Policy \& Development Abstrocts (SOPODA) - sociofile (SA and SOPODA on CD-ROM) - Products are available in print; online from Knight-Ridder, DIMDI, OCLC, and Ovid; on CD-ROM from SilverPlatler, EBSCO and Ovid; on magnetic tape via SAl direct. 


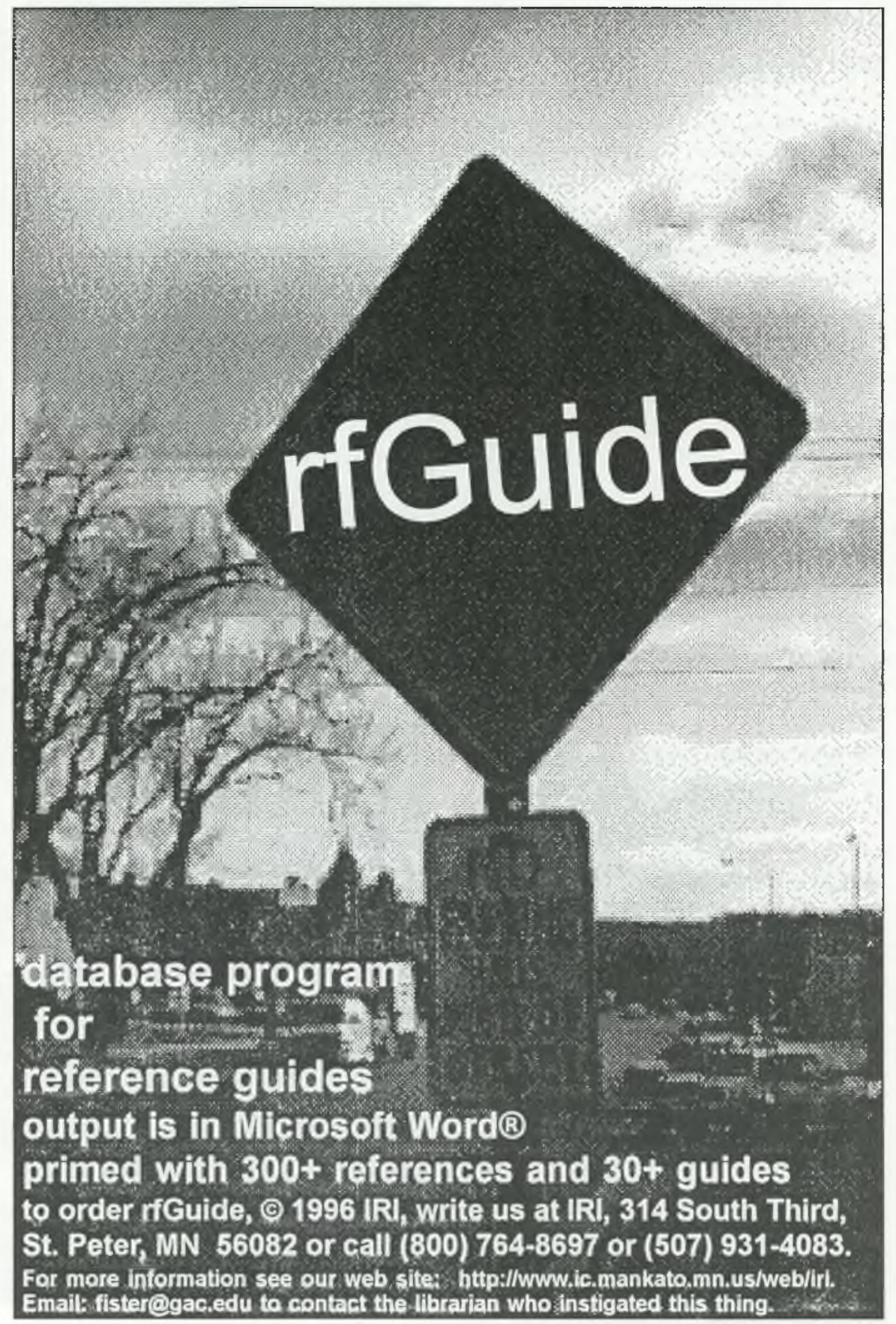

